\title{
A PAIXÃO SEGUNDO G. $H$. ., DE CLARICE LISPECTOR E $O$ ESTRANGEIRO, DE ALBERT CAMUS: A PERCEPÇÃO DO ABSURDO ENTRE OS “MUROS” LÚCIDOS DA RAZÃO CONTRAPOSTO AO ITINERÁRIO DA PAIXÃO
}

\section{THE PASSION ACCORDING TO G. H., BY CLARICE LISPECTOR AND THE STRANGER, BY ALBERT CAMUS: THE PERCEPTION OF THE ABSURD BETWEEN THE LUCID “WALLS” OF REASON OPPOSED TO THE ITINERARY OF PASSION}

Deivity Kássio Correia Cabral'

RESUMO: Neste texto aproximarei duas forças que constituem a alma e a consciência humanas: a paixão (pathos) e a razão (logos). O lócus de minha investigação percorrerá as narrativas literárias: $A$ paixão segundo G.H, de Clarice Lispector e $\mathrm{O}$ estrangeiro, de Albert Camus, suscitando nuances discursivas, contrapostas às ambas narrativas; isto é, os excessos metafóricos e a depuração discursiva. No primeiro ato será de irremediável importância, entendermos que toda estética está aliciada a uma ética; uma razão que manipula estratégias técnico-formais na exposição de um pensamento abstrato. No segundo ato, aprofundarei a pulsão vital que conduz toda inspiração criativa: a paixão, uma vez que, segundo Aristóteles, toda pulsão está a serviço da razão. Neste paradoxo, seja pelo frêmito das emoções ou pela ética imposta pela razão, o absurdo existencial se revela nos atos e nos hábitos das personagens, mostrando-as o grande dilema moral entre o homem e a irracionalidade do mundo.

PALAVRAS-CHAVE: Estudos Literários. Filosofia. Existencialismo. Absurdo.

ABSTRACT: In this text, I will try to enclose two forces that constitute human soul and consciousness: passion (pathos) and reason (logos). The lócus of research will be the literary narratives: The passion according to $G$. $H$., by Clarice Lispector and The stranger, by Albert Camus, bringing discursive nuances, opposed to both narratives; that is, metaphorical excesses and discursive purification. In the first act, it will matter that we understood that all aesthetics is enticed by an ethics; a reason that manipulates technicalformal strategies in the exhibition of an abstract thought. In the second act, I will analyze the vital drive that leads to all creative inspiration: passion, because, according to Aristotle, every drive is on duty to reason. In this paradox, whether through the thrill of emotions or over the ethics imposed by reason, the existential absurd reveals itself in the acts and habits of the characters, showing them the great moral dilemma between man and the irrationality of the world.

KEYWORDS: Literary studies. Philosophy. Existentialism. The absurd.

Submetido em: 15 out. 2018 Aprovado em: 29 nov. 2018

\footnotetext{
' Licenciatura em Letras, Língua Portuguesa da Universidade Federal do Recôncavo da Bahia. E-mail: dkcabral@outlook.com.
} 


\section{Introdução: entrelaces do ético ao estético}

No decorrer deste trabalho tentarei aproximar (entendendo suas singularidades) duas escrituras enigmáticas que, aparentemente, antagônicas, contornam dilemas morais semelhantes. Em busca de perceber diálogos sutis entre o ético e o estético, bem como o dizer pessoal de cada escritor sobre a vida e o absurdo que é existir, alguns elementos temático-formais serão explorados, revelando seja num jogo de emoções, seja num depuramento discursivo, uma unidade "concreta e intuitiva"1 de criação. Nesta trama, vida e ficção estarão unidos, nos levando a alcançar - sob uma "vertiginosa força monótona"2 - o confronto moral-metafísico do Absurdo3.

Antes de adentrarmos à análise das duas obras $A$ paixão segundo $G$. $H$. (PSGH), de Clarice Lispector e O estrangeiro (OE), de Albert Camus, Bakhtin (2002) expõe uma particularidade importante no ato de produção artística; o autor se refere à própria compreensão leitora, cujo olhar está imbricado ao juízo ético do autor. Para Bakhtin (2002) a ética do autor é indissolúvel à tessitura literária, pois que posiciona e constrói objetos estéticos na transmissão de uma realidade que preexiste à criação artística; isto é, é a intenção do autor que visa seduzir o olhar do leitor, direcionando-o a pensamentos e posicionamentos desconhecidos aos seus princípios de realidade. À vista disso, a arte (a Literatura especificamente) não se afasta da realidade costumeira vivenciada pelo leitor; ao contrário, segundo o autor: "A atividade estética[...] enriquece-as e complementa-as, e sobretudo ela cria a unidade concreta e intuitiva desses dois mundos" (BAKHTIN, 2002, p. 33).

Partindo dessa primeira noção, ao olharmos os valores estéticos a serem comparados, deveremos considerar o estilo e os objetivos de cada escritor. Clarice Lispector, à contrapelo de Albert Camus, tem como intento criativo a exteriorização de seus abismos interiores. A forma estética de Clarice se

\footnotetext{
${ }^{1}$ Bakhtin, 2002, p. 33.

2 Barthes, 2004.

${ }^{3}$ Entendo o conceito de Absurdo com base na tese filosófica de Albert Camus que propõe uma nova moral a existência do homem. O Absurdo "é o confronto entre esse irracional e esse desejo apaixonado de clareza cujo apelo ressoa no mais profundo do homem. $\mathrm{O}$ absurdo depende tanto do homem quanto do mundo. É, no momento, o único laço entre os dois. Cola-os um ao outro como só o ódio pode fundir os seres. É tudo o que posso discernir nesse universo sem limites em que prossegue a minha aventura" (CAMUS, 1942, p. 20).
} 
canaliza num frêmito passional; sua verborragia tenta alcançar, estruturalmente, os lugares pouco visitados da mente, explorando a arbitrariedade do signo: significante/significado. Mais especificamente, Clarice é uma escritora comprometida com o ser sob linguagem, naquilo que Olga de Sá (1979, p. 22) afirma como a "espessura do ser". A narração clariceana nos ensina a caminhar por nossos desertos interiores, rumo à neutralidade de respostas, a neutralidade de identidade e a descoberta do "segredo mais remoto do mundo" (LISPECTOR, PSGH, 2009, p. 137).

De acordo com Assis Brasil, Clarice Lispector engendrou diversas ficções, em especial a $P S G H$, mais voltada para o conhecimento filosófico de que para os aspectos formais da ficção. Logo, para ele, "desenvolve-se no romance um pensamento não uma vida, o que leva a reconhecer uma coerência filosófica em Clarice [...]" (ASSIS BRASIL apud AMARAL, 2005, p. 101). No entanto, a autora não é uma filosofa, muito menos uma pensadora, sendo o cerne de seu ato criativo uma busca incessante de entendimento da própria vida. Em vista disso, sua prática reflexiva lhe exige um canal concreto de expressão, sendo a linguagem literária a forma justa e comunicadora de suas experiências pessoais, permitindo-lhe encontrar os mesmos desafios que muitos filósofos no ato de escrever.

Paralelamente, vemos Albert Camus, filósofo franco-argelino, que opta pelo canal artístico na exposição de seus pressupostos filosóficos. É indubitável a manipulação estratégica de Camus, que se apropria dos mecanismos do romance "como suporte concreto do pensamento abstrato" (BARRETO, 1971, p. 144). Logo, o escritor se aproxima da Literatura para tornar concretas suas ideias, suas investigações ontológicas. Há uma pretensão moral tácita na escritura camusiana, submersa sob as linhas das palavras, objetivamente, postas.

Todavia, antes de tecer relações, estéticas e éticas, em torno da obra de Camus, considero aquilo que Maurice Blanchot dissertara, no livro $A$ parte do fogo, sobre um tipo específico de romance, o romance de tese:

Reconhecidos como meios de conhecimento, a arte e mesmo o romance estão obrigatoriamente destinados a se encontrar com outras disciplinas intelectuais. Esse encontro nada tem de extraordinário, foi 
quase uma constante em toda a história do pensamento. Dos présocráticos a Dante, de Leonardo da Vinci a Goethe, de Cervantes a Kafka, a história está repleta de obras de arte que não apenas expõem ideias, mas também as encontram, não se contentam em ilustrar certa imagem da nossa condição, mas a aprofundam e transformam. (BLANCHOT, 1997, p. 189, grifo meu).

Blanchot, ao falar do romance de tese, direciona nosso olhar às relações conjuntas da Literatura e da Filosofia. Blanchot (1997), o filósofo, exercendo o papel de investigador, expõe suas ideias intricado com a matéria da linguagem, posto ser este o canal de comunicação da filosofia, no qual viabiliza seus conceitos e teorias. Logo assim, não só Camus, mas milhares de filósofos, desde os pré-socráticos, produziram raciocínios, juízos éticos por meio de um trabalho estético. Entretanto, para que tal ato tivesse aprofundamento e forma, as próprias ideias tiveram que ser fundidas aos objetos estetizados - isto é, paisagem, linguagem, personagens etc.) - formando um todo "concreto e intuitivo" imerso na realidade da cultura e do conhecimento filosófico. O trabalho estético, melhor dizendo, a arte de dramatizar tornou-se, portanto, participante do conhecimento filosófico, haja vista a Literatura ser uma constituição entre o conhecimento intuitivo e estético.

Atendo-me ainda ao excerto anterior, é de total importância enfatizar o que Blanchot (1997) afirmara sobre as obras conceituadas, as quais "[...] não se contentam em ilustrar certa imagem da nossa condição[...]”. A imagem é a pedra angular do escritor-filósofo, à qual ele utiliza como artificie no processo escritural, ilustrando tanto as paisagens, quanto a existência e o cotidiano absurdo das personagens. Camus é um entre esses escritores-filósofos, cuja expressão sugere os recursos da imaginação do leitor como modo de conter o falatório mentiroso, aliciado pelo discurso burocrático, repleto de ambiguidades. 0 escritor Camus, portanto, corta à palavra uma significação-padrão, centrada em um lugar-comum, trazendo à forma uma razão, desconectada de um estrato social, possibilitando a disseminação de múltiplos pensamentos. A imagem, à vista do que foi dito, é o único modo capaz de subverter a norma da linguagem, sendo dever do filósofo/escritor "aprofundá-la" e "transformá-la" na busca de uma expressão pungente.

Albert Camus, assim como Sartre, Malraux entre outros filósofos, se lançaram ao trabalho artístico (em específico na arte literária) na busca de 
solucionar o sofrimento e o desamparo que a sociedade no pós-guerra, século $X X$, estava vivendo. Milhares de pessoas deserdadas de sonhos, valores, democracia e principalmente razão. Camus renuncia os ideais absolutos do passado, advindo de Hegel e demais escritores românticos, e busca a concretude de novos valores, baseados na experiência absurda da condição humana.

\begin{abstract}
O homem vive num mundo por ele recusado. A sua contradição, que 0 divide, consiste em recusar sem fugir. A consciência do homem revoltado faz com que ele perceba que a vida é um desenrolar contínuo de realizações parciais. Encontramos alegrias e tristezas, dúvidas ou certezas, que sempre terminam por nos transmitir 0 sentimento de que somos estranhos a esse mundo. O verdadeiro conhecimento que irá terminar por reconciliar o homem consigo mesmo somente será encontrado na morte. (BARRETO, 1991, p. 104-105, gripo meu).
\end{abstract}

O que Vicente Barreto argumenta é intrínseco ao sentimento de revolta e indiferença vivida pelo homem absurdo. O autor disserta sobre as diferentes atitudes e raciocínios escolhidos pelo homem movido pela revolta, frente aquele homem movido pelo totalitarismo. O que Barreto quer nos dizer se decifra no próprio sentimento do absurdo, conhecimento profundo que afasta o homem de qualquer atitude ou paixão extremista. Albert Camus, em sua tese do Absurdo pretende despertar, conscientemente, o homem diante do sistema convencional, fazê-lo analisar o mundo irracional, escondido em face do hábito, uma vez que "a consciência do homem revoltado [aquele que é consciente de sua vida] faz com que ele perceba que a vida é um desenrolar contínuo de realizações parciais". Tudo é incerto. Tudo é um desenrolar constante de eventos imprevistos, no qual somos perseguidos pelo destino mortal.

Nesta querela entre elementos internos à obra literária e extraliterários (biográficos, sociais e filosóficos) prosseguiremos à analise proposta, compreendendo de antemão que o juízo ético está envolto de pulsões instituais (pathos) e ambos estão a serviço da razão (logos). De acordo com Gérard Lebrun (2009, p. 11) :"Sem dúvida, devemos aprender a viver em conformidade com o logos, mas sem esquecer que as paixões continuam sendo a matéria de nossa conduta[...]. Paixão e razão são inseparáveis [...]". 
À vista disso, ambos escritores se submetem a diferentes ímpetos emocionais na expressão de distintas impressões estéticas; isto é, Clarice se vale do fluxo de consciência, do discurso verborrágico e dos eflúvios emocionais, enquanto, adversamente, vemos Camus, valendo-se da virtuosidade, da depuração discursiva e de uma descrição realista e objetiva. As personagens destes escritores voltam-se para o absurdo da condição humana: G. H. movida por suas percepções sensíveis, busca uma razão para sua experiência epifânica, a qual Ihe destituiu de sua humanidade; e Meursault, limitado por sua lucidez, priva-se do equívoco sentimental, sabendo ser este atributo da linguagem. Todos estes elementos estéticos estão aliciados a uma ética, sendo a proposta deste artigo aclarar as tendências (paixão ou razão) preexistentes à criação literária. Independentemente do modo de expressão, ambos escritores problematizam a condição existencial do homem: seus hábitos morais, "verdadeiros" e "belos", e a própria realidade que em si mesma lhes ultrapassa.

\section{Paixão e razão: caminhos interstícios da existência}

Em reflexão sobre ambas as obras investigadas: $A$ paixão segundo $G$. $H$., de Clarice Lispector e $O$ estrangeiro, de Albert Camus, um pensamento profundo fez-se necessário trazer à luz, à consciência questionadora dos leitores que as obras inquietaram. Situo-me, melhor dizendo, nas distintas impressões estéticas, condutoras a diferentes experiências de sentido, como também a simultâneas, porém contrárias tendências emocionais. Ao lermos ambas obras estaremos em duelo com aquilo que Orhan Pamuk (2011, p. 30) chama de "a natureza da ficcionalidade do romance". Tanto em $P S G H$, quanto em $O E$, seremos confrontados com um enigma - G. H. diante de uma barata e Meursault diante de um tribunal - que aparentemente revela-se incompreensível, mas foi pensado para atingir um objetivo maior: desmascarar a convenção humana. Durante a leitura, nos questionaremos: qual o sentido dessa história? O que o autor pretende ao retratar acerca de determinadas situações? Quem é Meursault? 0 que é G. H.? São questionamentos feitos pelos leitores na busca de decifrar se aquelas cenas e personagens baseiam-se "em experiências concretas ou na imaginação do autor" (PAMUK, 2011, p. 31). 
Além de pensarmos na ficcionalidade do romance, é importante percebermos as tonalidades afetivas quando afirmo "simultâneas e contrárias" tendências, pois que mesmo sob o fluxo da paixão, seremos exigidos a medir o grau de nossos atos. Neste âmbito, o juízo ético torna-se o mediador de nossas emoções nos levando à razão, à virtude diante dos romances comparados. Tanto a paixão, quanto a razão são movimentos simultâneos: a paixão como possibilidade e mobilidade na busca de nossos desejos; e a razão, sendo o princípio avaliativo da "intensidade passional" de nossas atitudes em diversas situações.

Assim, entendo o conceito de "tendência", enquanto representação de nossos sentidos advindos de nossos impulsos instituais, nos impelindo a uma atitude de raiva, de dor, amor ou indiferença. Segundo Aristóteles (apud LEBRUN, 2009, p. 17, grifo do autor) o que nos leva "a agir é o pensamento enquanto dirigido para um fim. Ora, é sempre uma pulsão (Oréxis) que estabelece o fim; o primeiro motor de uma ação é sempre objeto de uma pulsão".

Com base no pensamento de Aristóteles, devemos prosseguir às análises das duas obras, entendendo a pulsão como motor primordial tanto no processo de escrita, quanto na nossa capacidade de ler e sentir as nuances emocionais de uma determinada obra. Quando Aristóteles diz que "toda" ação se inicia pelo movimento de uma pulsão, evidencia o processo construtivo da própria escrita, pois que as tendências emocionais (ou recusas sentimentais) são atitudes inevitáveis tanto ao se ler OE como PSGH; obras, esteticamente, movidas e construídas pelo fluxo da paixão (pathos).

No entanto, saliento que embora a escrita de Camus possa ter origem na força canalizada do pathos, a trama narrada não dará margem a prevalência dos desejos; ao contrário, $O E$ revelará a face oposta a paixão: a razão (logos), baseado num pensamento lúcido e numa conduta precisa e objetiva. Holanda (1992, p. 23) ao analisar $O E$, afirmou: "O primeiro movimento de Mersault [personagem-narrador] é o de tirar da palavra o pathos que nela pesa e impede uma relação livre com o mundo".

Deste modo, seguindo a ótica teórica de Lebrun (2009), o paradoxo categórico concernente a força energética da paixão e a virtuosidade da razão, se situa num debate filosófico que desde a Grécia antiga pairava entre os 
principais filósofos clássicos: Platão, Aristóteles e Sócrates, contraposto aos postulados dos estoicos. Pensar na paixão é perceber os diversos sentimentos que nos tomam de sobressalto seja quando enfrentamos um engarrafamento em um dia quente, quando brigamos com alguém ou somos demitidos do trabalho, etc. Diversas situações nos impelem a uma reação, a uma tendência, embora a nossa atitude nem sempre seja satisfatória, eticamente, e nem os acontecimentos nos levem a dominar nossos impulsos interiores.

Portanto, é necessário medir a gravidade desta reação e a relevância do que sentimos, sendo a mensuração e o juízo ético de nossos sentimentos frutos da razão (o logos). Aristóteles, segundo Lebrun (2009), esclarece que "o pathos não é uma força que colocará permanentemente obstáculos à alma razoável: ele está a serviço do logos e em consonância com ele". À vista disso, Lebrun propõe uma outra nomenclatura para identificar essa atitude equilibrada frente aos atos extremos da paixão: a virtude, tendência que nos conduzirá à razoabilidade de nossos atos.

Partindo desse pressuposto, teremos um ponto em comum ao direcionarmos o nosso olhar às duas obras; isto é, seja conduzido pela via da paixão, num discurso passional - como será visto na confissão verborrágica de G. H. - ou pela regularidade e virtuosidade posta pela razão - o discurso lúcido e perspicaz de Mersault -, e desvelaremos o enigma da existência: a decisão moral-metafísica do homem frente a irracionalidade da existência.

Nesta perspectiva, tanto ao analisar a personagem de PSGH - que prossegue um itinerário existencial na busca de sua própria identidade -, quanto ao adentrarmos à vida de Meursault, personagem-narrador de $O E$ - que desde os primeiros atos narrados torna-se uma sombra à grande clareza exigida pelo leitor - o Absurdo persegue, silenciosamente, os passos das personagens:

Fiquei quieta. Minha respiração era leve, superficial. Eu tinha agora uma sensação de irremediável. $E$ já sabia que, embora absurdamente, eu só teria ainda chance de sair dali se encarasse frontal e absurdamente que alguma coisa estava sendo irremediável. Eu sabia que tinha de admitir o perigo em que eu estava, mesmo consciente de que era loucura acreditar num perigo inteiramente inexistente. Mas eu tinha de acreditar em mim - a vida toda eu estivera como todo o mundo em perigo - mas agora, para poder sair, eu tinha a responsabilidade alucinada de ter de saber disso. (LISPECTOR, PSGH, 2009, p. 50, grifos meus). 
A personagem G. H., movida pela busca irremediável de encontrar respostas a sua origem humana, percorre os cômodos de sua casa - o apartamento que até um certo momento lhe era familiar - na expectativa de perceber os rastros de sua vida primária, neutra. No entanto, ao adentrar o mais interno da casa (o quarto da empregada), respostas, signos, sentimentos, lembranças e súbitas reflexões são originadas, Ihe retirando do seu hábito banal e lhe impelindo ao núcleo imanente da própria vida. Percebe-se nos fragmentos anteriores, nas linhas grifadas, expressões de espanto e proximidade da personagem com algo que lhe era indiferente. G. H. ao adentrar os cômodos da casa, paralelamente, adentrava os corredores de sua alma, sendo sua última descoberta, o encontro inesperado com uma barata, a representação do seu "outro" reverso.

\begin{abstract}
A barata é um ser feio e brilhante. A barata é pelo avesso. Não, não, ela mesma não tem lado direito nem avesso: ela é aquilo. $\mathbf{O}$ que nela é exposto é o que me mim eu escondo: de meu lado a ser exposto fiz o meu avesso ignorado. (LISPECTOR, PSGH, p. 76, grifo meu).
\end{abstract}

A sensação de irremediável se interliga ao próprio estado de abandono da personagem frente ao absurdo. O início deste confronto, o encontro, absurdamente, inexorável com a barata, Ihe destituiu de suas antigas certezas e organizações. G. H., em seu itinerário metafísico, percorre tanto o inconsciente coletivo, ancestral da humanidade, quanto se encaminha à maturidade de sua condição de mulher e à revelação imanente da identidade. $\mathrm{O}$ inseto lhe destituiu de suas antigas normalidades, revelou-Ihe a identidade original da raça humana e lhe expôs a visão indisfarçável do seu "eu" soterrado pelo peso da civilização. Segundo Nunes (2009, p. 315) ao dissertar sobre a experiência de G. H., a metamorfose "desmorona o sistema social, desorganiza a engrenagem psicológica, desfaz a inserção no cotidiano que lhe assegurava a estabilidade agregativa de um Eu como máscara postiça, reconhecida pelos Outros; [propondo] uma volta às origens [...]".

Consequentemente, teremos uma personagem passional, que não pode ser vista como uma voz passiva, submissa ao destino; aliás, a passionalidade, a 
atitude paciente de G. H. é de um "poder tornar-se"4. A personagem trilha seu itinerário já forçada pelo primeiro ato de dizer, mesmo tendo a consciência do malogro de sua voz, da insuficiência do verbo burocratizado. Nesta perspectiva, as surpresas durante o caminho lhe arrebatarão afetivamente, propondo novas tendências e revelações: "Fiquei quieta. Minha respiração era leve, superficial. Eu tinha agora uma sensação de irremediável". Optando por querer e ansiar saber, se autoconhecer, que todas as desorganizações se fundem ao "eu" de G.H., influenciando no seu discurso e nos atos perpetrados na narrativa.

Do outro lado da balança, "desapropriando-se do mundo" (HOLANDA, 1992, p. 71), reduzindo-se ao silêncio e em conformidade aos princípios racionais, vemos Mersault, apático ao seu próprio mundo, um sujeito que nada mais insiste, questiona ou rejeita; aliás, a única coisa que a personagem rejeita é a fala, nada além do necessário:

Dormi durante quase todo o trajeto. E, quando acordei, estava caído sobre um soldado, que sorriu e me perguntou se eu vinha de longe. Respondi "sim" para não ter de falar mais. (CAMUS, OE, 1979, p. 10, grifo meu).

Em OE, de Albert Camus, seremos desarmados: não há um tempo histórico, nem tampouco sobrepujamento subjetivo, flutuações emocionais, descrições psicológicas de caráter das personagens, quanto menos seremos envolvidos pelo frêmito de palavras poéticas. O estilo de Camus renega a força passional, e de forma racional, depura os excessos sentimentais e discursivos. Olhemos para o excerto anterior, em orações justapostas e quase se resumido à coerência das orações simples, somos levados pela indiferença e individualidade do sujeito enunciado que se afasta para nada dizer; "dizendo", apenas, por meio do advérbio de negação: "não".

Atravessando uma escrita concisa e direta, Camus não se propõe a desvelar os recônditos da alma humana - ideia estrita ao estilo intimista de Clarice que seduz e impressiona. O estrangeiro, de acordo com Barthes (2004), rege um "estilo invisível", sendo tecido numa percepção estética silenciosa,

\footnotetext{
${ }^{4}$ Considero está expressão mais coerente com as atitudes da personagem G. H., partindo do pressuposto de que a paixão, o fenômeno passional, segundo Aristóteles apud Lebrun (2009) é "tudo que faz variar os juízos, e de que se seguem sofrimento e prazer". Ora, a personagem se entrega as percepções da alma, então ela age conforme as suas sensações.
} 
afastada de qualquer explicação. Assim, torna-se, primordial, a descrição pura e detalhada de uma experiência narrada e vivida pelo próprio personagemnarrador, frente ao Absurdo que se mascara sob sua própria condição existencial.

\begin{abstract}
O que Camus nos propõe já não é um ato com ecos, um ato totalmente enviscado no estrato das causas, das justificações, das consequências e das durações; é um ato puro, inconsequente, separado de seus vizinhos, suficientemente sólido para manifestar uma submissão ao absurdo do mundo e suficientemente breve para fazer explodir a recusa a comprometer-se com ilusórias justificações desse absurdo (BARTHES, 2004, p. 95).
\end{abstract}

Quando Meursault foi questionado pelo seu patrão se não queria mudar de vida, a resposta do personagem foi muito simples e objetiva: "nunca se muda de vida; que, em todo caso, todas equivaliam, e que a minha, aqui, não me desagradava em absoluto". (CAMUS, OE, 1979, p. 46). Sob atos enigmáticos, o absurdo se adensa ao olhar do leitor diante da indiferença e recusa de Meursault a expressar mais daquilo que ele sente. A narrativa camusiana solicita experiência, perspicácia e acima de tudo observação. Os fatos são expostos de forma pura, sem o suposto "enviscamento" às causas que regem nosso ato. A narrativa espelha o nosso cotidiano, em que o absurdo reina subjacente ao nosso olhar, pensamentos e atitudes irrefletidas.

É perceptível, nesta análise comparatista, os aspectos paradoxais entre as narrativas literárias, em que o fluir escritural de PSGH nos invade por múltiplos desejos arrebatadores, desencadeadores de sensações e acontecimentos inconscientes. A personagem G. H., em sua travessia mística, numa acuidade reflexiva, nos expõe à dialética das sensações: paixão/ódio; desejo/santidade; Deus/inferno; humano/inumano; transcendência/imanência; sendo estes conceitos representações dos dilemas morais da personagem, posto que G. H. não conhecia a profundidade de seu estar-no-mundo. É preciso compreender que G. H. caminha para o plano primário da vida, a raiz neutra da identidade; suas reflexões existenciais lhe despertam do hábito humanizado, acarretando na percepção do absurdo numa macrovisão metafórica, irracional e sentimental.

Camus bem fala que a razão do absurdo não está contra nossa existência, mas nos propõe uma nova condição (BARRETO, 1991, p. 65). Apesar de ser 
inexplicável a existência humana e de tudo que nos limita, é preciso equilibrar as emoções e não ceder a princípios morais que retiram do homem sua verdadeira revolta. Por isto que Meursault se situa a posteriori de G. H., pois o personagem atribui lucidez às suas atitudes e sentimentos diante da existência:

Com Meursault é a "impostura" do discurso o que é denunciado. A posição de Meursault é mais negativa [...]. À pulsão que o esporeia se junta a consciência crítica que o freia. Posição mais ética e menos natural, consequentemente, de quem, porque se pensa, se poda. (HOLANDA, 1992, p. 63)

É nessa atitude balizadora que o equilíbrio das emoções pode encontrar veemência na escritura literária. "À pulsão que o esporei se junta a consciência crítica que o freia". Meursault freia a falácia, freia a angústia sem propósitos, freia a convenção que o separa do seu ato. Assim sendo, a percepção do absurdo para Meursault já é passado; agora, a moral é o "como" lidar com a disparidade entre a consciência sedenta de respostas e o limite de sua própria vida, decorrente à morte.

É importante considerar que todos estes aspectos comentados não podem ser vistos apenas como uma abordagem técnica. Exige-se do leitor que contemple ambas narrativas e permita-se às suas leituras de maneira atenta e simpática, tendo a compreensão que a relação parte do nosso próprio contexto de vida em diálogo com o outro; isto é, a cada acontecimento: gestos, escolhas, falas e atitudes, lidas e imaginadas, tornam-se autênticos retratos às experiências vividas no passado ou presente de nossa história.

Ambos escritores se propõem a diferentes manejos de linguagem, como, anteriormente falado: Clarice Lispector rege um estilo passional, expondo as profundezas da alma de maneira afetiva, íntima, rebuscada, voltada aos impulsos emotivos. Albert Camus, genuinamente, constrói uma narrativa enigmática até o fim "da qual não se pode extrair nada, a não a ser as evidências e a descrição absurda" (BARTHES, 2004). Ambos problematizam a condição existencial do homem: seus hábitos morais, verdadeiros e belos, e a própria realidade, que na percepção simultânea, lhes é indiferente.

Com base em tudo que foi falado, situo como temática e eixo central de ambas narrativas, a discussão em torno da existência humana. A paixão (pathos) 
e a razão (logos) nos conduzirão ao dilema moral do Absurdo cuja condição vital do homem: suas origens, realidade e o destino (a morte) se desterram à consciência da humanidade diante de sua suposta liberdade. $\mathrm{O}$ intuito deste texto é de refletir os sentidos estéticos que povoam a existência ficcional dos personagens. Ser passional ou agir em harmonia entre as pulsões instituais, não nos impede de aproximar da mesma verdade que nos assusta: o absurdo de existir. Cito Camus (apud BARRETO, p. 65): "O absurdo de uma coisa não é uma razão contra a sua existência. É mais uma condição".

É a esta condição que seremos lançados e aliciados a enfrentar, seja por vias estilísticas distintas seja por tendências emocionais também diferenciadas. Em a PSGH, atravessaremos um relato sensível, permitindo à nossa compreensão antever o "outro" incógnito numa linguagem que segundo a própria autora: "não se necessita entender não é uma questão de inteligência e sim de sentir, de entrar em contato" (LISPECTOR apud AMARAL, 2005, p. 23). Em paralelo, confrontaremos uma outra estética aparentemente inacessível que se afasta para melhor se aproximar, dizendo por meio da negação. O personagem camusiano rejeita o verbo, por saber que a linguagem abstrai o real. Ao passo de negar a fala, o personagem, captura, realisticamente, a vida absurda do homem, sujeitado à ambiguidade do verbo pela "presença em ausência". 0 estrangeiro nos exige vivência, uma inteligência mais afiada em que o leitor entenda o drama descrito como reflexo atemporal de uma experiência distante, porém presente.

Em diálogo com ambas escrituras, pude constatar que naquilo que pensamos ser G. H.: passional, passiva, melindrosa, uma personagem suscetível a sentimentos inconstantes, veremos, no decorrer de seu itinerário, um sujeito ativo, se movimentando, arduamente, à lapidação, transformação e à sua irremediável metamorfose. Contraposto, Meursault exerce o ato de negação, uma negação sobrejacente a um sim. O sim do personagem é a revolta à razão do mundo. Portanto, na iminência de dizermos "sim" a tudo, tornamo-nos passivos às circunstâncias. Entretanto, a passividade de Meursault não está ligada à moralidade do mundo, "todo esse gestual da passividade é assuminada por Meursault numa espécie de transe, que é o estado de indiferença fundamental às razões do mundo" (BARTHES, 2004, p. 93). Sua atitude é lúcida 
diante da irracionalidade da sua condição. Por mais que ele se revolte com o mundo, este não deixará de ser o que é: um limite sem recursos à compreensão do homem.

Cada um de nós vive o absurdo, no entanto, cada um o descobrirá de uma maneira particular, tomando a revolta como fator de sobrevivência. Foi imbuído de uma completa revolta que Meursault renunciou a fala desmedida e sujeitada do poder burocrático. Assim, privou-se de atos e falas intermediadas pela convenção, numa decisão lúcida e compactuada pela verdade. Consoante, Barthes (2004, p. 48) reforça que a obra de Camus "incomoda uma ordem qualquer da natureza; interrompe uma hierarquia do universo; desorganiza uma explicação e faz calar uma mentira [...]". O estilo de $O$ estrangeiro, se resume, ainda de acordo com Barthes, num nonsense, mas este "não-sentido" se reflete no não-sentido da criação, no não-sentido de nossa própria existência.

\section{Percursos históricos: recepção literária}

Ao entendermos como se constrói as narrativas supracitadas, partindo do pressuposto de que velado a uma estética há uma ética, uma manipulação formal e semântica da linguagem, é preciso compreender a época de surgimento de ambos escritores e de suas respectivas narrativas. Adentro este arcabouço teórico para consolidar tudo aquilo, anteriormente, analisado no percurso deste trabalho. Para tanto, parto de algumas noções críticas rastreadas na historicidade de ambas narrativas em análise, levando em consideração os aspectos interpretativos que abordam as escrituras em sua ampla sistemacidade: autor-obra-recepção.

Clarice Lispector irrompe na Literatura Brasileira, em 1944, com o livro Perto do coração selvagem, recebendo inusitadas proposições críticas de muitos estudiosos da Literatura pelo seu rompimento estilístico com a tradição clássica: baseada nos ideais de narrativa realista, linear e de relato documental das questões sócio-políticas do país.

De acordo com Sá (1979, p. 42, grifo meu): 
do seu dicionário pessoal. A extraordinária carga emocional que os seus vocábulos carregam, aquelas palavras-chaves produzem um efeito que é antes de tudo estético. Estético e eficaz.

A estilística das sensações se associa à própria peculiaridade estética e às temáticas narrativas dos enredos clariceanos. Numa linha histórica de produções da autora, quase todas as personagens criadas caminham a momentos culminantes de fortes sensações emocionais, sendo revelada uma visão profunda de suas próprias existências. Diante disso, um aspecto contrastante causou um certo estranhamento entre a estética intimista da autora aos preceitos da crítica, baseada numa estética realista - isto é, fator denunciante que acarretou no confronto e na renovação do formalismo estético tradicional. Clarice Lispector, neste paradoxo, passou a ser vista como escritora de literatura para "mulherzinha", posto que seu compromisso não estava mais engessado numa realidade externa, mas sim numa perspectiva de realidade interior.

É nesta perspectiva de desvendar, projetar seus descontentamentos interiores pelo canal arbitrário da linguagem que boa parte de suas personagens serão tomada por múltiplas contradições: o ser versus sua humanidade; santidade versus pecado; identidade versus alteridade, razão versus emoção etc. Benedito Nunes, um entre tantos críticos mais comentados ao se pensar na escritura clariceana, se debruçara sobre as diversas narrativas da autora, reatualizando antigas interpretações e expandindo as margens suas observações. Uma dentre tantas obras comentadas pelo crítico foi PSGH: a enigmática travessia da paixão de G. H., que segundo a nomeação de Nunes, poder-se-á ser chamada de via mística. Segundo o autor, a personagem é seduzida por um mundo abismal, sua descoberta the retirou de sua vida envolvente e Ihe situou no núcleo imanente de sua própria vida. Entretanto, para tal acontecimento se dar início, fora imprescindível a presença contrastante de um ser externo a condição de G. H., precedendo mais uma oposição entre tantas que a personagem irá enfrentar:

O confronto com a barata marca o início de uma ruptura não apenas com essa maneira de viver, mas com a engrenagem - com o sistema geral dos hábitos mundanos. Mediador de violenta e completa desorganização do mundo humano, o animal exterioriza as forças 
traiçoeiras que solapam a estabilidade desse mundo e que desalojam G. H. do círculo da existência cotidiana. A partir dos momentos em que a personagem, a caminho do quarto de empregada, transpõe a parte social do apartamento, já se faz sentir, na área de serviço, estendendose por todo o edifício, a ação sorrateira de tais forças estranhas. (NUNES, 1989, p. 61)

As forças estranhas, pronunciadas por Nunes, advêm da descida escatológica, ancestral, remota da personagem. Essas forças estão localizadas no próprio interior de G. H. que, no contínuo ato de descida, de passagem e cedendo a um ritual de desagregação, busca, absurdamente, a nascente onde brota o rio caudaloso da existência humana. G. H. cede ao desconhecido como forma de entender sua própria condição que também lhe é estranha. Nunes (1989), no seu texto O itinerário místico de G. H., aponta, veementemente, essa ascese mística de conversão da personagem, cujas oposições anteriormente citadas não serão processadas se a personagem não atingir a tentadora existência impessoal.

É a partir da impessoalidade, da intransitividade que o oposto se funde à lógica humana de G. H. É preciso ir além do que é visível, moral, belo para conhecer a "existência substantiva pura" (1989, p. 69). Assim, partindo dessa perspectiva de análise, pude perceber que através desse jogo de oposições, desse confronto catártico de que G. H. se aproximara, uma primeira experiência tivera que ser consumada em prol de um amadurecimento de sua realidade interior. Após tal experiência, dessa mística subtração individual, a exteriorização tivera que ser realizada, pois que a necessidade de compartilhamento, de completude, se fez necessária à personagem, concedendo a mesma transmutação a uma segunda pessoa.

Propondo um último referencial teórico, Emília Amaral, no livro O leitor segundo G. H., expõe um outro âmbito de análise, no qual mais se volta ao universo que intermedeia o leitor e a narrativa, em detrimento de demais aspectos de análise da macrovisão clariceana. Num primeiro momento a autora se volta ao tipo de receptor que a narrativa clariceana exige. No começo do livro de a PSGH, é possível vermos um pacto de leitura, no qual a personagemnarrador convida o leitor a seguir um caminho que é feito de situações e experiências opostas à lógica convencional. 
Este livro é como um livro qualquer. Mas eu ficaria contente se fosse lido apenas por pessoas de alma já formada. Aquelas que sabem que a aproximação do que quer que seja, se faz gradualmente e penosamente - atravessando inclusive o oposto daquilo de que se vai aproximar. [...] (LISPECTOR, PSHG, 2009, p. 5, grifo meu).

É por meio deste intuito que Clarice inicia a sua ficção, levando tanto Amaral (2005), quanto os seus milhares de leitores a se debruçarem sobre uma complexa, vital e metamórfica narrativa. Assim, não apenas acompanharemos o ato de confissão da personagem, como também viveremos, sentiremos a sua transmutação "verbo-identitária" ao longo de seu itinerário. A partir deste suposto contrato de leitura, Emília expande os eixos de sua análise, partindo desde o discurso labiríntico até o surgimento necessário de uma segunda pessoa, o interlocutor de G. H., meio facilitador da personagem manter o seu discurso e não se perder nos interditos de sua própria fala.

\begin{abstract}
Neste contexto, o interlocutor surge ao mesmo tempo como ameaça e defesa, como deflagrador do processo da escritura e como o seu possível cerceador. Diante disso, G. H. afasta-se dele, mas o faz atraindo-o, pois desnuda seu desamparo, sua angustia, sua situação de risco/perigo. (AMARAL, 2005, p. 75).
\end{abstract}

Portanto, Amaral evoca a imagem do leitor como canal fluido para que processo escritural de G. H. tivesse sua consumação. É por meio do leitor que a confissão é tecida, sendo a imagem desse outro interior ou exterior independentemente do lugar que ele esteja - que a personagem não perderá seus antigos sentidos, podendo voltar atrás para não ser "esmagada pelo acaso". No entanto, a personagem decide ir até o fim de sua experiência, reduzindo a narrativa ao total silenciamento, pois que as imagens do outro, do interlocutor, do leitor, são abandonadas, provisoriamente, cerceando o relato em construção.

No decorrer desta contextualização de perspectivas de análise sobre a narrativa clariceana, é importante frisar que boa parte dos estudos realizados sobre Clarice Lispector e sobre suas respectivas obras literárias foram baseadas em três vertentes analíticas: crítica feminista, crítica psicanalítica e a crítica voltada ao universo da linguagem (AMARAL, 2005, p. 90). A análise, neste trabalho, foi pensada e voltada para o universo da linguagem, entretanto, na iminência com que nos aproximamos da linguagem, desvelamos outros 
domínios de investigação que acima ou abaixo da linha das palavras, encontram condições vitais para a sua subsistência. Pensar na escritura clariceana e camusiana, antes de qualquer passo, é preciso pensar na linguagem, pois que é através das atitudes e discursos das personagens que desvendaremos a problemática filosófica subjacente.

A contrapelo vemos a figura e o grande estilista que é Albert Camus, um escritor que soube pelo equilíbrio das pulsões retratar o externo de maneira neutra e precisa.

Para que uma obra seja absurda é necessária uma integração entre o sentimento e a inteligência. $O$ absurdo da obra de arte consiste precisamente no fato de que a inteligência aparece como o elemento ordenador. A inteligência renuncia à tarefa de racionalizar o concreto, limitando-se a ordená-lo. (BARRETO, 1971, p. 62).

Na busca de uma forma, de uma fala justa, de um elemento ordenador às suas abstrações filosóficas, Camus viu no romance um meio capaz de transpor e criticar as convenções sociais e os valores destituídos pelo próprio homem, em razão de ideias românticas e irracionais. Vicente Barreto (1971), no livro Camus: vida e obra, discute diversos ensinamentos do legado filosófico de Albert Camus: a felicidade, o absurdo, a revolta, os romances, etc. Diversos fatores que edificam o imaginário crítico do filosofo e de cuja contribuição serviu e serve como artefato orientador ao destino do homem após a metade do século XX. De certa maneira, o pensamento do filósofo influenciou na cultura e na consciência individual e coletiva na nossa contemporaneidade. O que chamarei atenção na obra deste crítico, jurista e pensador, é referente à estética de Camus, que segundo o autor: "Na estética de Camus podem ser encontrados três estilos: o estilo absurdo, o estilo revoltado e o estilo poético" (BARRETO, 1971, p. 155).

Atendo-me à primeira estética, é a partir da noção do Absurdo que entenderemos o porquê dos atos de Meursault, como também da narração concisa e árida presente em OE. Para Barreto (1971), o estilo absurdo "é feito sob medida"; isto é, a disparidade entre Meursault e o mundo começa pela linguagem; nesta perspectiva, o ritmo, o estilo, a organicidade oratória do texto devem retratar a indiferença verbal e existencial do personagem frente ao mundo. Camus (apud BARRETO, 1971, p. 144) ao dissertar sobre a relação 
entre o romancista e o filósofo afirmara: "a forma é a relação que se deve estabelecer entre o real e o pensamento". Não há como compreender o Absurdismo de Camus sem se debruçar na fonte literária de cujo artificie foi depositário das abstrações do filosofo e tornou-se canal concreto de seus exercícios filosóficos. Foi e é através de personagens "reais" que Camus expressou o nonsense da relação entre o homem e o mundo que lhe ultrapassa.

Ainda de acordo com Barreto (1971), deveremos entender a escritura camusiana sob dois planos distintos e contínuos: o primeiro plano é o da objetividade, em que o mundo ficcional - os atos das personagens, bem como a sucessão dos fatos - são descritos de maneira neutra, abstendo explicações despropositadas; e no segundo plano, submerso às descrições, há uma moral sorrateira, em que o autor, conjecturando um pensamento, instala nas atitudes das personagens, o espelho de nossas vidas. A vida de Meursault, em OE, é tratada de maneira habitual, regida de diálogos breves e as atitudes narradas se revestem de inexplicável. O personagem é guiado por consequências e contingências; a moral que funda a narrativa não se exterioriza, mas se revela no próposito da criação que retrata a descontinuidade da vida, transmitindo "a impressão do fragmentário e do abrupto" (BARRETO, 1971, p. 147).

Meursault não aprofunda reflexões perante seus atos, sua conduta é simples e sem segundas intenções. Não há percepção psicológica. 0 personagem age na pureza correspondente ao seu pensamento, movido de uma certa ingenuidade; logo, sendo direto e relegando falsos sentimentos, Meursault é condenado por sua perplexidade diante de valores tolos justificados pela convenção humana.

Situando um último trabalho voltado à linguagem, o silêncio e os "sismos sociais" que afloram subjacente à obra O estrangeiro, Lourival Holanda (1992), de forma analítica, num trabalho conjunto entre a inteligência crítica e o olhar poético, tece comparações a partir das obras OE e Vidas secas. No início de seu ensaio, o autor faz algumas considerações de cujos elementos: da escrita e do objeto problematizador serão projetados sob novas roupagens em sua análise. O primeiro elemento não terá qualquer linearidade, apenas o estilo circular como "Volteios de voo de urubu", fugindo do peso da dissertação acadêmica; e o segundo elemento é definidor, o autor sabendo que "toda estética traz 
subjacente uma ética", frustra a pretensão do senso comum, de simplesmente trabalhar o conteúdo contraposto à forma. Assim, Holanda se volta para linguagem literária como canal concreto e de múltiplos sentidos.

Assim, partindo da forma narrativa, o autor levanta alguns pressupostos sobre a postura literária de Albert Camus, sendo predominante o silêncio conjugado no impacto da escritura:

Em $O$ Estrangeiro esse silêncio vem se inscrever sob outra forma mas fundamentalmente semelhante: Meursault é quem, calado, na recusa técnica acusa a carga de mentira que a linguagem veicula - e, assim, o sistema que a funda. (HOLANDA, 1992, p. 17).

Holanda reconhece o silêncio tanto em Albert Camus, quanto em Graciliano Ramos como canal latente de escamotear uma moral prescrita, direcionando o leitor a uma forma de resposta que se desvela sob "fulgor da ausência”. O texto literário tangencia sentimentos e percepções do leitor na proposta de torná-lo mais observador e perquiridor do universo ali engendrado. Em Sob o signo do silêncio, o crítico parte da linguagem literária como projeto estético conjugado a uma ética preexistente. Holanda, neste ensaio, reconhece que Camus adotou certas perspectivas de escrita como modo de encerrar enganosas flutuações emocionais e dar vazão à percepção do absurdo inscrita nos atos habituais da personagem. É como enunciado por Barthes (2004) ao se referir ao estilo de $O$ estrangeiro: "tácita e incômoda, ela se suspende no olhar de todos como um nonsense tão inelutável, quanto o próprio nonsense da criação". O que Camus objetiva é depurar os acréscimos humanos: linguagem excessiva, sentimentos enganosos e reflexões secundárias das atitudes das personagens, como modo de tornar perceptível o não-sentido das relações humanas. Numa condensação do objeto imaginado, Camus distancia o leitor de possíveis análises psicológicas e o reflete na realidade que está sendo: objetiva, absurda e opaca.

Holanda (1992), portanto, durante sua análise-poética, pressupõe um novo enfoque da narrativa camusiana, de cujo entendimento à tese inscrita não será processada se não compreendermos o modo como a história foi estruturada. O escritor precisa compreender sua própria realidade e acoplar uma "forma de efetuar a imitação" (HOLANDA, 1992, p. 24). Partindo dessa ideia, 
Camus, na busca de inovar, de modernizar a forma de narrar, segundo Holanda (1992, p. 25), "desromanciza” o próprio romance. Aquilo que era enquadrado sobre o estudo do romance: a ação, o estudo dos personagens e o enredo, se reduz a economia linguística e a exposição de imagens sucessivas.

Camus atesta a ambiguidade da fala e a irracionalidade do mundo à luz da razão humana, posto que seu propósito, é revelar estas premissas, instalando "um estranhamento no discurso". Para isso as lacunas nos interstícios das sentenças e a "economia descritiva", se instituem vias formais de expor a vacuidade do verbo na elucidação de uma racionalidade a este mundo inapreensível.

Camus surge na Literatura Mundial em 1942 com a obra O estrangeiro. Considerado por Barthes um dos grandes representantes da literatura do pósguerra, é visto ainda hoje sob uma compreensão irracional e lido de maneira superficial, desconsiderando-se o mar abissal da sua escritura; isto é, a leitura de $O$ estrangeiro é rápida e aprazível, exigindo um maior aprofundamento do leitor, pois que nada é feito pelo escritor sem ter um intuito maior. Uma forma sempre vem influenciada por valores e experiências exteriores, às quais, preexistem a obra literária, fundindo-se a ela pela forma estetizada. Assim, pouco discutida, a literatura de Camus torna-se mal compreendida aos olhares desatentos dos leitores.

No entanto, na época do lançamento de $O$ estrangeiro, Camus ganhou muita visibilidade no mundo da literatura, visto, até mesmo, como porta-voz da sociedade no século XX. Camus, juntamente a Malraux, Sartre, Gide e outros, transpuseram para as suas obras o desespero e o deserdamento histórico e social que todos os povos estavam sofrendo naquele momento. Milhares de homens e mulheres diante dos desastres capitais que dizimaram milhões de pessoas, se encontravam deserdados de sonhos, esperanças, liberdade, democracia e até mesmo razão. Diante de tal cenário, o Absurdo, a Revolta e o Suicídio, temas caros ao pensamento camusiano, propõem discutir e protagonizar a existência do homem, viabilizando uma resolução para as frustrações humanas.

Enfim, como foi frisado anteriormente, a humanidade, desde o pós-guerra, estava deserdada de qualquer valor, inclusive de razão. Camus, nesse embate, 
parte em busca de um mundo novo em que o próprio homem tivesse a consciência de enfrentar sua condição moral-metafísica, recomeçando a viver de uma forma plena e lúcida. Uma vida para Camus se baseia no raciocínio absurdo, pois que permitirá ao homem existir entre as tensões que lhe angustiam; ou seja, sem elas (a consciência da condição humana e a realidade que nos ultrapassa) o absurdo não teria qualquer significação. Assim, é por meio de tais tensões que Camus propõe como centro norteador o equilíbrio e a razoabilidade da consciência humana, premissas que permitirão ao homem viver diante de sua condição desesperadora.

\section{Considerações finais}

Por meio desta análise de simultaneidades e diferenças, tanto entre estéticas distintas, quanto entre tendências emocionais opostas, situo ambos escritores e suas respectivas narrativas. No entanto, as dissemelhanças apenas se espraiam nos níveis superficiais de recepção. Quando o poder da palavra submerge o leitor nas profundezas da escritura, os diálogos, veladamente, inscritos, se revelam múltiplos e amalgamados com existência. Assim, anterior a qualquer uma das "verdades" estabelecidas, o enigma existencial é o eixo principal que percorre as narrativas, tendo em vista os caminhos interstícios da paixão e da razão como forças condutoras do homem e seu ato de amadurecimento diante da vida.

Em uma narrativa, $A$ paixão segundo $G$. $H$. acompanharemos uma trajetória marcada pelo frêmito passional, direcionada aos impulsos sensíveis, em que a própria personagem estará mergulhada numa insaciabilidade e transgressão reflexiva de seus desejos e revelações inenarráveis. Em $O$ estrangeiro, o movimento se reduz e se consolida para o nada; cito Holanda (1992, p. 66) "O que escreve sabe: para além do mito moderno da singularidade, o que se rediz, se reduz [...] (grifo meu) ". Meursault, numa trajetória circunstancial, enfrenta o mundo de maneira realista e objetiva, se revelando um personagem virtuoso e indiferente ao conformismo social. Quando Holanda (1992) diz que "o que se rediz, se reduz", a própria recusa sentimental e verbal 
de Meursault, leva-o a reconhecer a insuficiência da linguagem e a insanidade dos valores humanos.

Independentemente, dos efeitos que o pathos nos causa e a moderação que o logos nos adverte, chegaremos numa contínua trajetória ao Absurdo interstício ao enigma da existência, uma vez que, em conformidade com Aristóteles, "o pathos está em consonância com o logos". Se ambos estão imbricados só resta ao homem, num ato ético, ponderar o movimento dessas tendências na busca de sua lucidez diante da existência absurda. A travessia literária se engendra sob estéticas e tendências distintas: G. H. cedendo as suas revelações emotivas e instituais; e o personagem camusiano se renegando a explicações redutivas sobre a vida humana. De forma inteligente, Meursault silencia e abrevia os impulsos da paixão.

\section{Referências}

AMARAL, Emília. O leitor segundo G. H.: uma análise do romance A paixão segundo G. H. de Clarice Lispector. Cotia, SP: Ateliê Editorial, 2005.

BAKHTIN, Mikhail. Questões de literatura e de estética. Tradução: Aurora F. Bernardini. São Paulo: Hucitec, 1988.

BARRETO, Vicente. Camus: vida e obra. Rio de Janeiro: José Alvaro Editor S.A., 1971.

BARTHES, Roland. Inéditos, vol.2: crítica. Tradução: Ivone Castilho Benedetti. São Paulo: Martins Fonte, 2004.

BLANCHOT, Maurice. A parte do fogo. Tradução: Ana Maria Scherer. Rio de Janeiro: Rocco, 1997.

CAMUS, Albert. O estrangeiro. Rio de Janeiro: Record, 1979.

CAMUS, Albert. O mito de Sísifo. Rio de Janeiro: Guanabara, 1942.

CAMUS, Albert. A inteligência e o cadafalso e outros ensaios. Tradução: Manuel Costa Pinto e Cristina Murachco. 3. ed. Rio de Janeiro: Record, 2010.

HOLANDA, Lourival. Sob o signo do silêncio: Vidas Secas e O Estrangeiro. São Paulo: EDUSP, 1992.

LEBRUN, Gérard. O conceito de paixão. In: NOVAES, Adauto. Os sentidos da paixão. São Paulo: FUNARTE/Companhia das Letras, 2009. 
LISPECTOR, Clarice. A paixão segundo G. H. Rio de Janeiro: Rocco, 2009.

NUNES, Benedito. O drama da linguagem: uma leitura de Clarice Lispector. São Paulo: Ática, 1989.

NUNES, Benedito. A paixão de Clarice Lispector. In: NOVAES, Adauto. Os sentidos da paixão. São Paulo: FUNARTE/Companhia das Letras, 2009.

PAMUK, Orhan. O romancista ingênuo e o sentimental. São Paulo:

Companhia das Letras, 2011.

SÁ, Olga de. A escritura de Clarice Lispector. Petrópolis: Vozes, 1979. 